\title{
ANALISIS DAMPAK PERUBAHAN IKLIM TERHADAP CURAH HUJAN TAHUNAN MENGGUNAKAN SKENARIO IKLIM HadCM3 DENGAN SKENARIO EMISI A2 DAN B2 ANALISIS DI DAS PROGO HULU
}

Slamet Suprayogi ${ }^{1}, 2$, Ahmad Cahyadi ${ }^{1}$, Tommy Andryan Tivianton ${ }^{1}$, Sugeng Riyadi ${ }^{1}$ Ahdi Ahmad Fajri², Tika Rahayu Sasongko², Vera Arida ${ }^{2}$ 1Jurusan Geografi Lingkungan, Fakultas Geografi,Universitas Gadjah Mada ${ }^{2}$ Prodi Ilmu Lingkungan Sekolah Pascasarjana Universitas Gadjah Mada Email: slametsuprayogi@yahoo.com, ahmadcahyadi@geo.ugm.ac.id

Perubahan iklim telah menjadi permasalahan global yang dampaknya diperkirakan sangat mengkhawatirkan bagi kehidupan manusia. Penelitian ini bertujuan untuk mengetahui dampak perubahan iklim terhadap curah hujan tahunan di DAS Progo Hulu. Metode yang digunakan adalah analisis perubahan iklim menggunakan Skenario iklim HadCM3 dengan skenario emisi A2 dan B2. Data curah hujan eksisting di wilayah kajian (meliputi 10 stasiun meteorologi) akan dianalisis menggunakan statistik downscalling dengan hasil pemodelan dalam skenario iklim dan emisi yang digunakan dalam penelitian ini. Hasil penelitian menunjukkan bahwa pemodelan perubahan iklim dengan menggunakan skenario emisi A2 menunjukkan 4 stasiun meteorologi menunjukkan jumlah curah hujan tahunan mengalami tren menurun, sedangkan 6 stasiun yang lain mengalami kenaikan. Hasil pemodelan dengan skenario emisi B2 menunjukkan hanya 2 stasiun yang mengalami penurunan curah hujan, sedangkan 8 stasiun yang lain di DAS Progo Hulu mengalami trend kenaikan curah hujan tahunan.

Kata Kunci: Perubahan Iklim, Curah Hujan Tahunan, HadCM3, Dowscalling, DAS Progo Hulu

\section{Pendahuluan}

Sejak Rachel Carson menulis buku dengan judul "The Silent Spring”, dunia seakan tebuka matanya akan banyaknya masalah lingungan yang sudah begitu hebat dampaknya bagi kehidupan manusia. Permasalahan lingkungan tersebut kemudian menyebabkan banyak masalah bagi kehidupan manusia seperti kegagalan panen, hilangnya banyak spesies hewan yang bermanfaat bagi kehidupan manusia baik secara langsung atau tidak langsung, perubahan musim dan bahkan terjadinya kemarau panjang yang menyebabkan banyaknya kematian manusia.

Salah satu permasalahan lingkungan yang banyak dibicarakan sejak awal tahun 1990-an adalah pemanasan global dan perubahan iklim. Fenomena ini telah banyak dikajinya oleh banyak peneliti. Hasil kajian tersebut menyatakan bahwa semakin banyak dampak negatif yang ditimbulkan oleh pemanasan global dan perubahan iklim di dunia.

Hasil penelitian beberapa peneliti menunjukkan pemanasan global dan perubahan iklim telah berdampak terhadap pada curah hujan tahunan di beberapa negara. Viglizzo, et 
al. (1995) mengungkapkan bahwa pemanasan global dan perubahan iklim telah menyebabkan kenaikan curah hujan tahunan di Argentina. Senada dengan hal tersebut, Plummer et al. (1999) mengungkapkan bahwa kenaikan curah hujan tahunan juga terjadi di Australia dan Selandia Baru. Meskipun demikian Hal berbeda diungkapkan oleh Mason (1996) yang mengungkapkan bahwa pemanasan global dan perubahan iklim ternyata justru menyebabkan penurunan curah hujan tahunan di Afrika. Penelitian yang memiliki kesimpulan yang sama dengan hal tersebut diantaranya diungkapkan oleh Zhai et al. (1999) dalam penelitiannya di Tiongkok, serta Masoudi dan Afrough (2011) yang melakukan penelitian di Iran.

Berdasarkan beberapa fakta yang diungkapkan sebelumnya, maka penelitian ini bertujuan untuk menganalisis dampak perubahan iklim terhadap curah hujan tahunan di DAS Progo Hulu. Hal ini sangat penting mengingat wilayah ini merupakan wilayah yang memasok sekitar 90\% air permukaan yang ada di Daerah Istimewa Yogyakarta. Wilayah ini juga berperan dalam pemenuhan kebutuhan air untuk persawahan dengan dibangunnya beberapa bendung yang mengalirkan airnya ke persawahan di Daerah Istimewa Yogyakarta, misalnya melalui Selokan Mataram atau Selokan van der Wijck. Selain itu, mulai Tahun 2015, Sungai Progo akan menjadi sumber air minum bagi Perusahaan Air Minum Daerah (PDAM) Tirta Marta yang akan memasok kebutuhan air minum di Kabupaten Sleman, Kabupaten Bantul dan Kota Yogyakarta.

\section{Metode Penelitian}

\section{Data yang Digunakan}

Beberapa data yang digunakan dalam penelitian ini disajikan dalam Tabel 1.

Tabel 1. Data, jenis data dan sumberdata dalam penelitian

\begin{tabular}{|l|c|c|c|l|}
\hline \multicolumn{1}{|c|}{ Tujuan } & Jenis Data & Keterangan & Sumber Data & $\begin{array}{l}\text { Digunakan } \\
\text { untuk }\end{array}$ \\
\hline $\begin{array}{l}\text { Proyeksi Kondisi } \\
\text { Iklim dengan } \\
\text { HadCM3 A2 dan } \\
\text { B2 }\end{array}$ & $\begin{array}{c}\text { Curah Hujan } \\
\text { Harian }\end{array}$ & $\begin{array}{c}\text { Tahun1971-2001 } \\
\text { Circulation Model }\end{array}$ & $\begin{array}{c}\text { BMKG DIY dan } \\
\text { PSDA Progo } \\
\text { Hulu-Oya }\end{array}$ & $\begin{array}{l}\text { Predictant file } \\
\text { untuk } \\
\text { Downscaling }\end{array}$ \\
\cline { 2 - 5 } & $\begin{array}{c}\text { Tahun1961-2099 } \\
\text { Grid DAS Progo } \\
\text { Hulu HadCM3 } \\
\text { Skenario A2 dan B2 } \\
\text { climate model }\end{array}$ & $\underline{\text { http://www.cccsn. }}$ & $\underline{\text { ca }}$ & $\begin{array}{l}\text { Input untuk } \\
\text { Downscaling }\end{array}$ \\
\cline { 2 - 5 } & $\begin{array}{c}\text { NCEP/ NCAR } \\
\text { Reanalysis }\end{array}$ & $\begin{array}{c}\text { Tahun 1961-2000 } \\
\text { Skenario A2 dan B2 }\end{array}$ & $\begin{array}{c}\text { http://www.ncep.n } \\
\text { oaa.gov }\end{array}$ & $\begin{array}{l}\text { Input untuk } \\
\text { Downscaling }\end{array}$ \\
\hline $\begin{array}{l}\text { Proyeksi Pola } \\
\text { Tanam Tahun } \\
\text { 2020an, 2050an, } \\
\text { dan 2080an } \\
\text { Skenario emisi } \\
\text { A2 dan B2 }\end{array}$ & $\begin{array}{c}\text { Curah Hujan } \\
\text { Tahunan Tahun } \\
\text { 2020an, 2050an, } \\
\text { dan 2080an } \\
\text { Skenario emisi A2 } \\
\text { dan B2 }\end{array}$ & $\begin{array}{c}\text { Tahun 2011-2040, } \\
\text { Tahun 2041-2070, } \\
\text { dan 2071-2099 } \\
\text { Skenario emisi A2 } \\
\text { dan B2 }\end{array}$ & $\begin{array}{c}\text { Hasil Pemodelan } \\
\text { Iklim dengan } \\
\text { Model HadCM3 } \\
\text { Skenario emisi A2 } \\
\text { dan B2 }\end{array}$ & $\begin{array}{l}\text { Penentuan } \\
\text { Pola Tanam } \\
\text { Meteorologis } \\
\text { Kondisi Masa } \\
\text { Mendatang }\end{array}$ \\
\hline
\end{tabular}




\section{Metode Analisis Dampak Perubahan Iklim}

Nilai kondisi iklim sampai dengan Tahun 2100 dalam penelitian ini diperoleh didasarkan pada Global Circulation Model (GCM). Model GCM menggunakan model HadCM3 yang dikeluarkan oleh UK Hadley Centre. Data yang diperoleh adalah data yang mewakili grid sebesar $2.5^{\circ} \times 3.75^{\circ}$. Hal tersebut menyebabkan hasil model dari metode tersebut masih cukup kasar, sehingga diperlukan adanya teknik downscaling untuk menghasilkan data yang lebih sesuai dengan wilayah kajian yang sempit (Wilby et al., 2008). Teknik analisis Downscaling dilakukan dengan seperti yang ditunjukkan oleh Gambar 1.

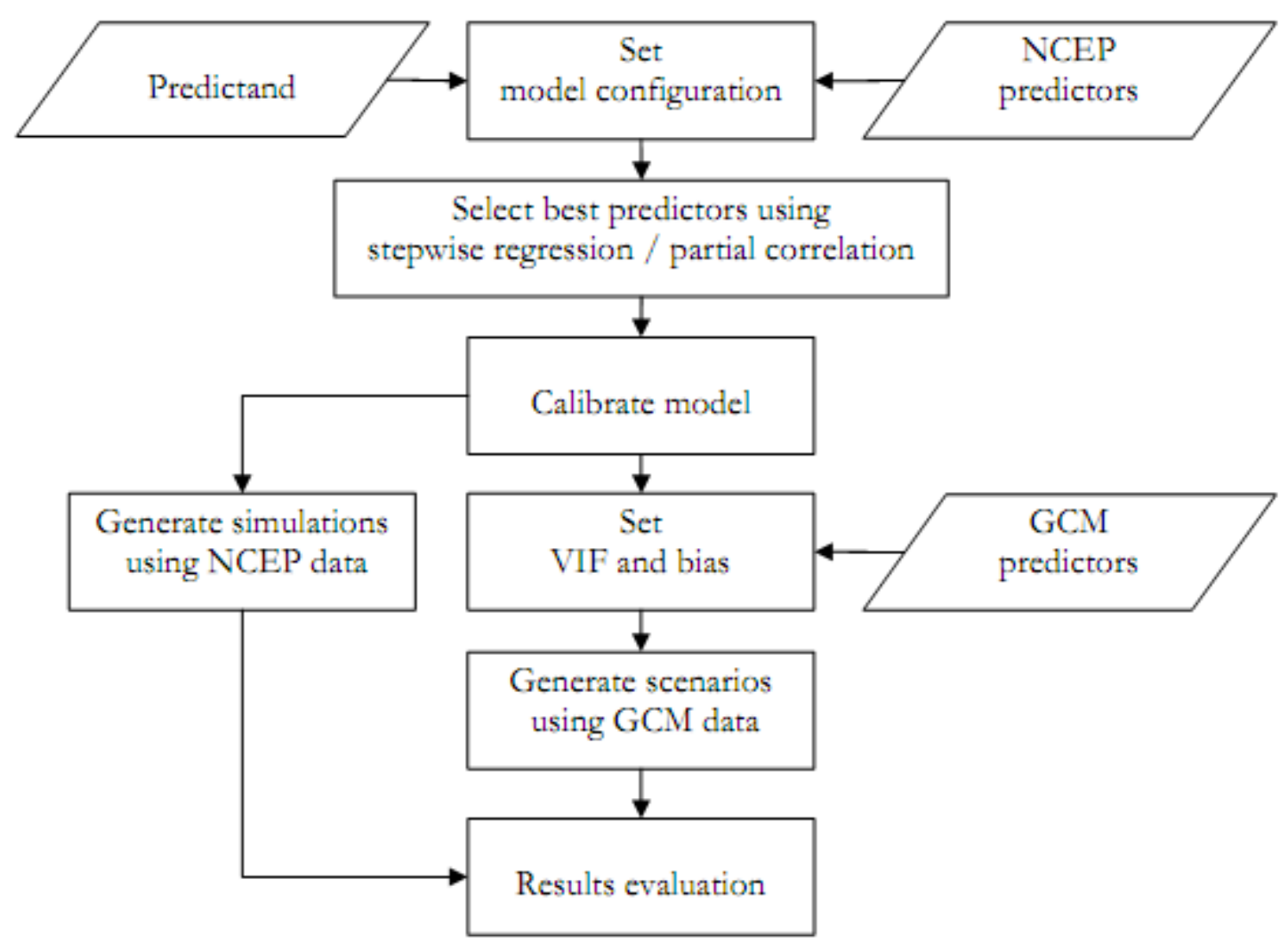

Gambar 1. Skema proses downscaling dengan ASD (Hessami et al.,2007)

Dampak perubahan iklim yang dikaji pada penelitian ini hanya dikaji pada skenario emisi A2 dan B2. Hal ini karena skenario emisi ini dianggap paling cocok dengan kondisi negara berkembang seperti Indonesia. Detail skenario emisi yang dapat digunakan dalam kajian perubahan iklim ditampilkan dalam Tabel 2. 
Tabel 2. Representasi kualitatif perubahan indeks kunci SRES

\begin{tabular}{|c|c|c|c|c|c|c|c|}
\hline Scenario & Population & Economy & Environment & Equity & Technology & Globalisation & Climate \\
\hline AIFI & & & & & & & \\
\hline AlB & & & & & & & \\
\hline AIT & & & & & & & \\
\hline BI & & & & & & & \\
\hline A2 & & & & & & & \\
\hline B2 & & & & & & & \\
\hline
\end{tabular}

\section{Hasil dan Pembahasan}

\section{Dampak Perubahan Iklim Terhadap Curah Hujan Tahunan di DAS Progo Hulu dengan Skenario Emisi A2}

Hasil pemodelan iklim dengan menggunakan scenario emisi A2 menunjukkan pengaruh yang berbeda-beda. Gambar 2. samapai dengan Gambar 6. menunjukkan bahwa beberapa stasiun mengalami trend kenaikan seperti Stasiun Barbadan, Borobudur, Dukun, Jumprit, Kaliangkrik dan Magelang, sedangkan stasiun lainnya menunjukkan trend penurunan jumlah hujan tahunan seperti Stasiun Cebongan, Kalijoho, Kintelan dan Parakan.

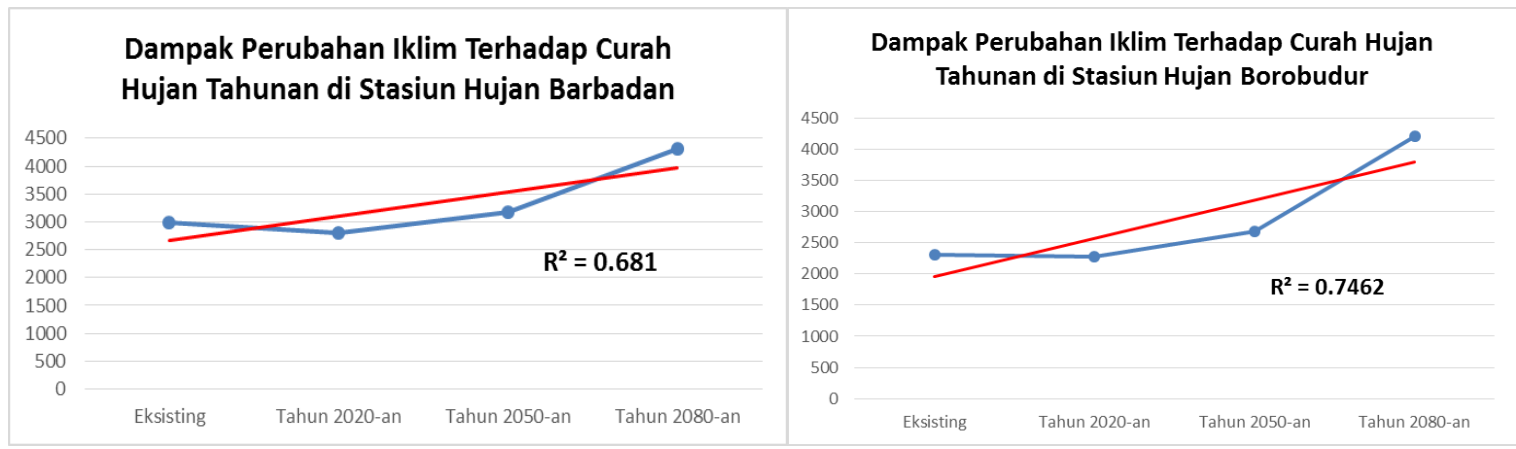

Gambar 2. Perubahan trend curah hujan tahunan di Stasiun Babadan dan Borobudur dengan emisi skenario $\mathrm{A} 2$ 


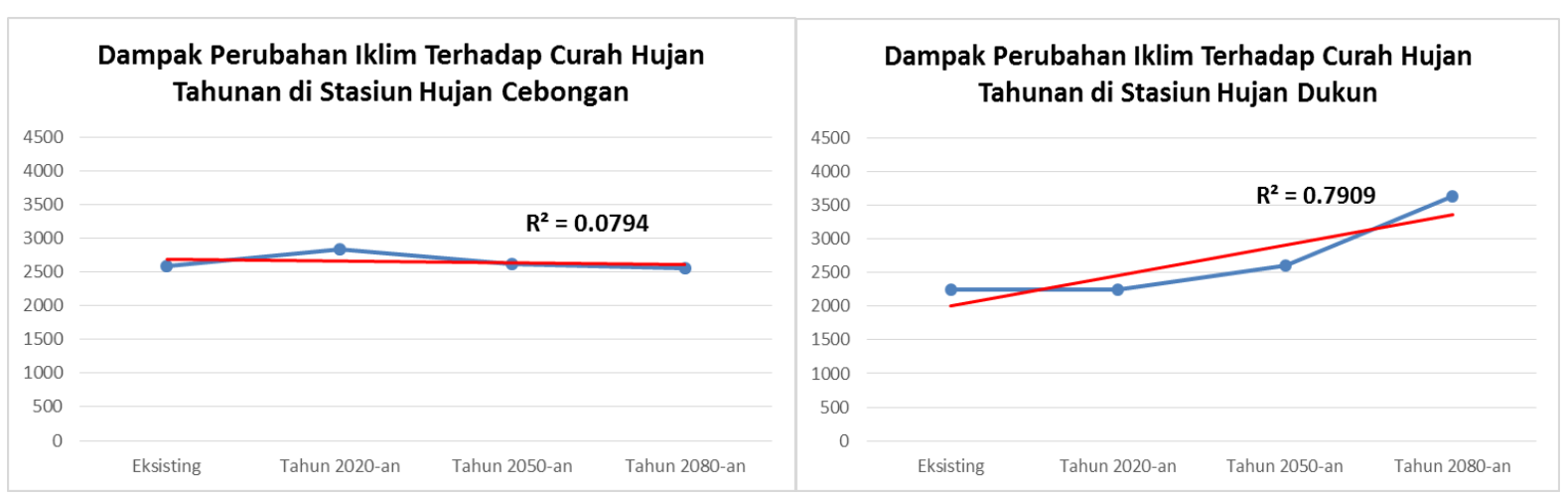

Gambar 3. Perubahan trend curah hujan tahunan di Stasiun Cebongan dan Dukun dengan emisi skenario A2

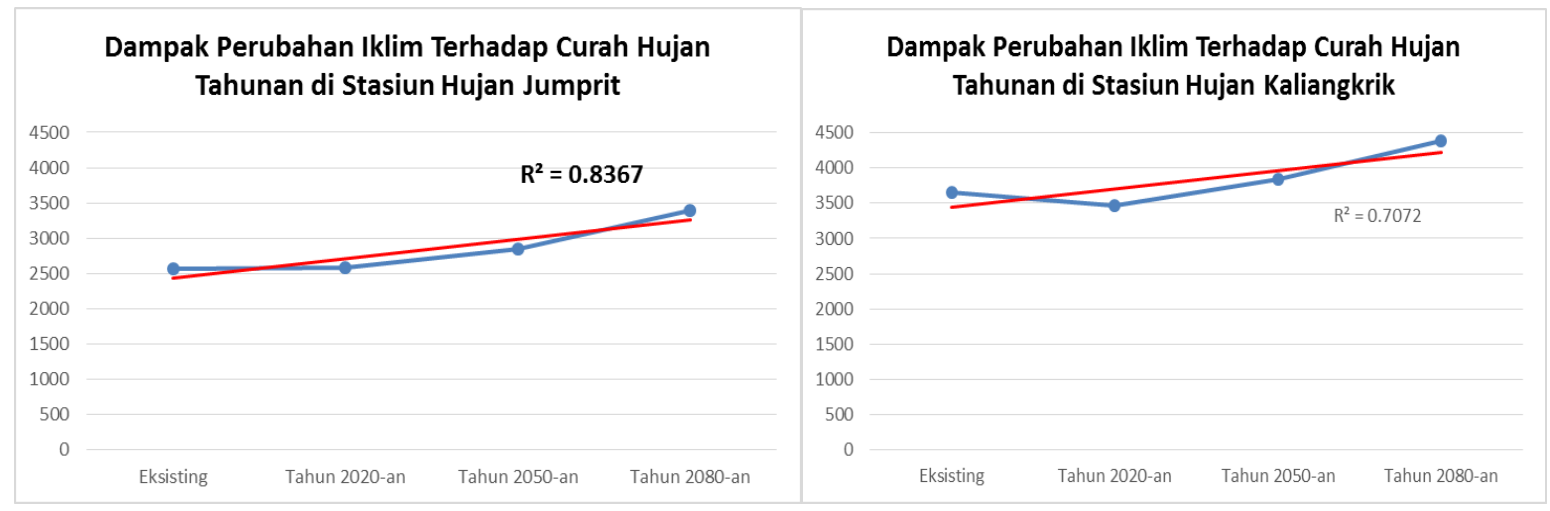

Gambar 4. Perubahan trend curah hujan tahunan di Stasiun Jumprit dan Kaliangkrik dengan emisi skenario $\mathrm{A} 2$

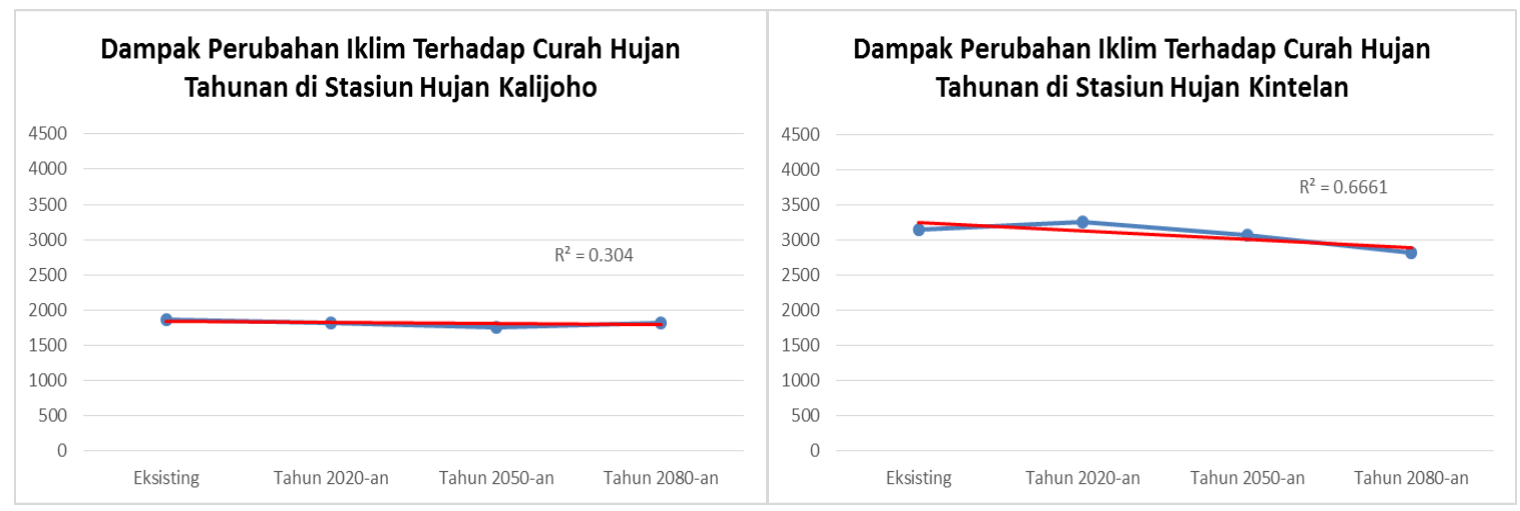

Gambar 5. Perubahan trend curah hujan tahunan di Stasiun Jumprit dan Kaliangkrik dengan emisi skenario $\mathrm{A} 2$ 


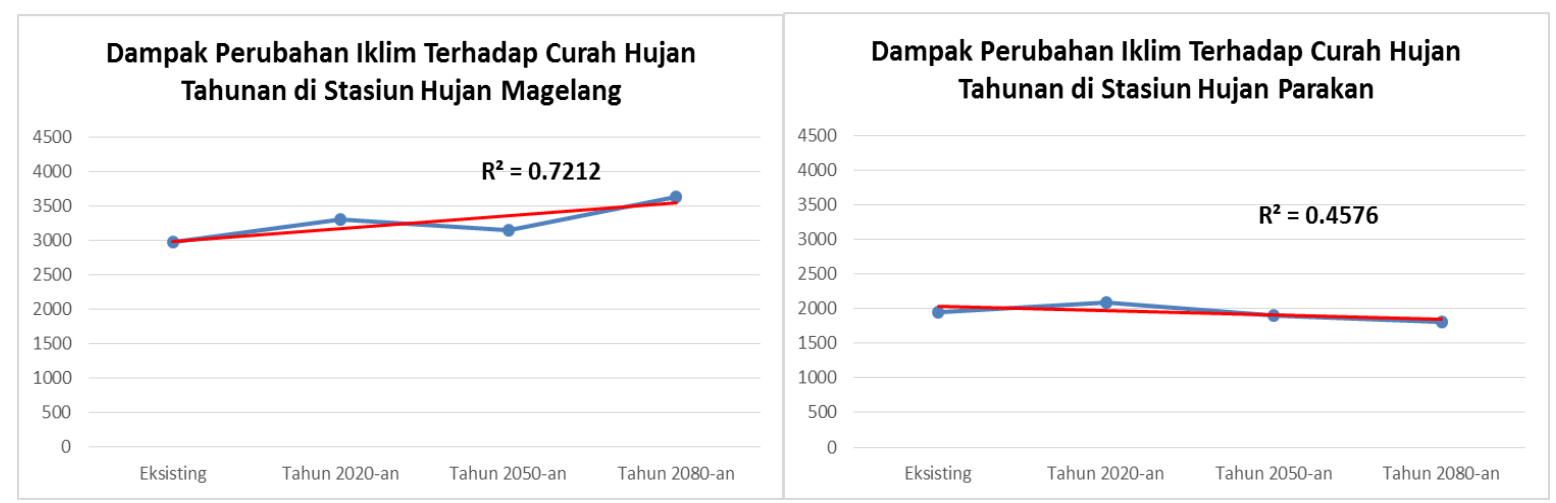

Gambar 6. Perubahan trend curah hujan tahunan di Stasiun Jumprit dan Kaliangkrik dengan emisi skenario A2

Apabila dilihat dengan skala per periode iklim (Gambar 7. sampai dengan Gambar 11.), maka diketahui secara lebih detail bahwa beberapa stasiun memiliki trend yang berubah selama tiga periode iklim. Stasiun yang memiliki trend yang berubah selama tiga periode iklim yaitu Cebongan. Di stasiun Cebongan, trend cenderung naik pada tahun 2020an sedangkan untuk tahun 2050-an dan 2080-an trendnya cenderun turun. Untuk stasiun Magelang dan Kalijoho trendnya cenderung naik untuk tiga periode iklim, namun nilai hujan tahunan pada tahun 2050-an lebih rendah dibandingkan pada tahun 2020-an. Stasiun yang konsisten memiliki trend naik yaitu Barbadan, Borobudur, Dukun, Jumprit dan Kaliangkrik. Dengan demikian, kemungkinan terjadinya kejadian banjir pada stasiun ini memiliki peluang yang tinggi untuk kedepannya dikarenakan nilai hujan tahunannya terus meningkat. Stasiun Parakan memiliki trend hujan tahunan yang cenderung turun dalam tiga periode iklim, demikian pula dengan stasiun Kintelan hanya saya stasiun Kintelan sempat mengalami kenaikan trend pada tahun 2050-an.
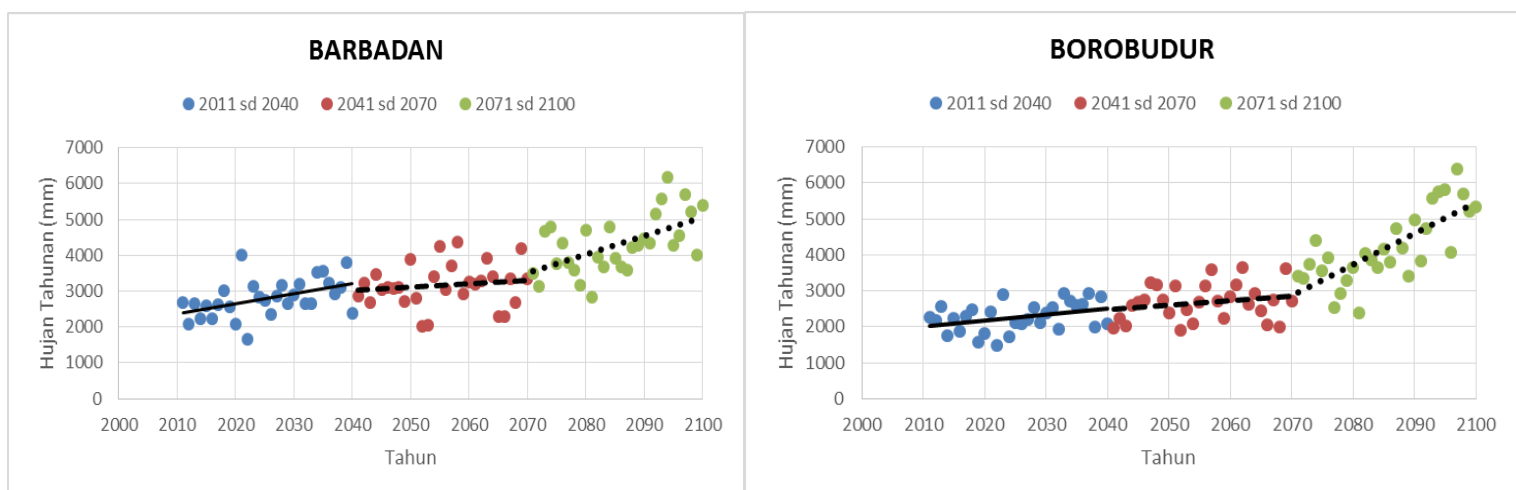

Gambar 7. Perubahan trend curah hujan tahunan pada masing-masing periode iklim di Stasiun Babadan dan Borobudur dengan emisi skenario A2 

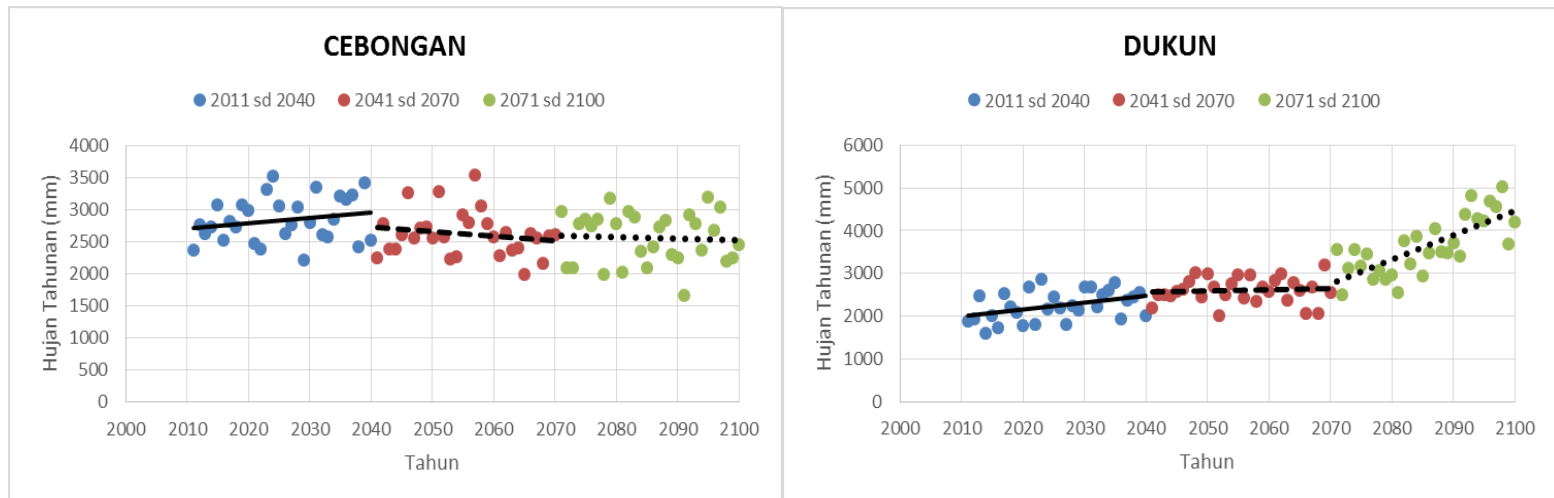

Gambar 8. Perubahan trend curah hujan tahunan pada masing-masing periode iklim di Stasiun Cebongan dan Dukun dengan emisi skenario A2
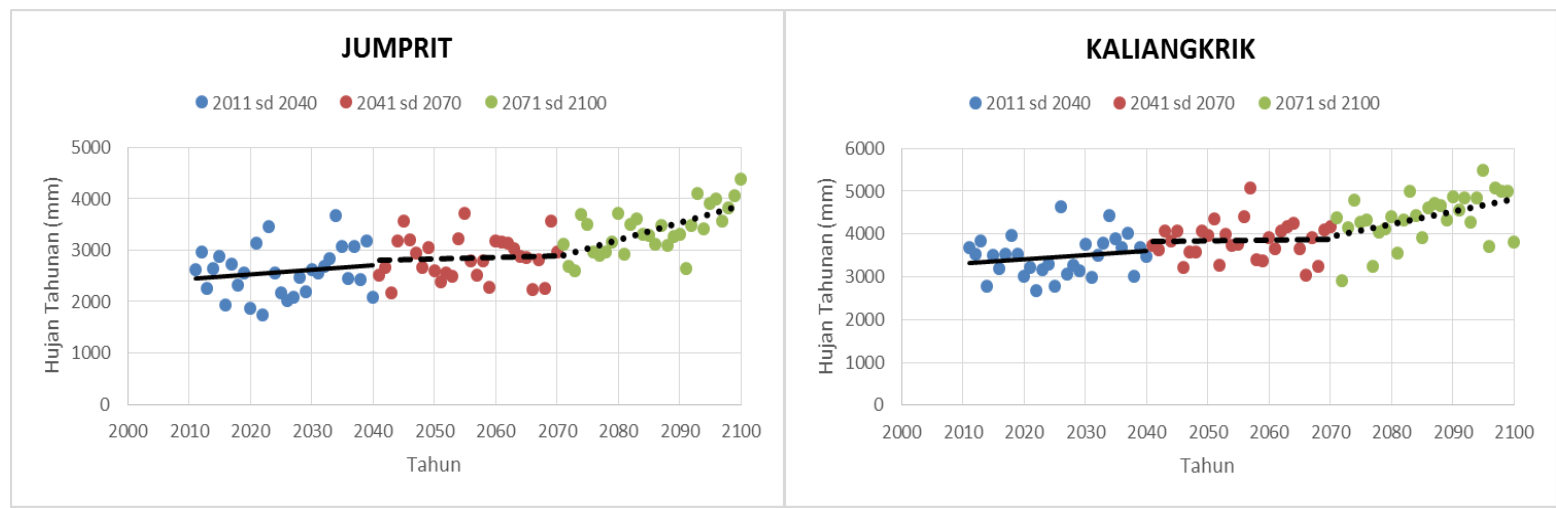

Gambar 9. Perubahan trend curah hujan tahunan pada masing-masing periode iklim di Stasiun Jumprit dan Kaliangkrik dengan emisi skenario A2
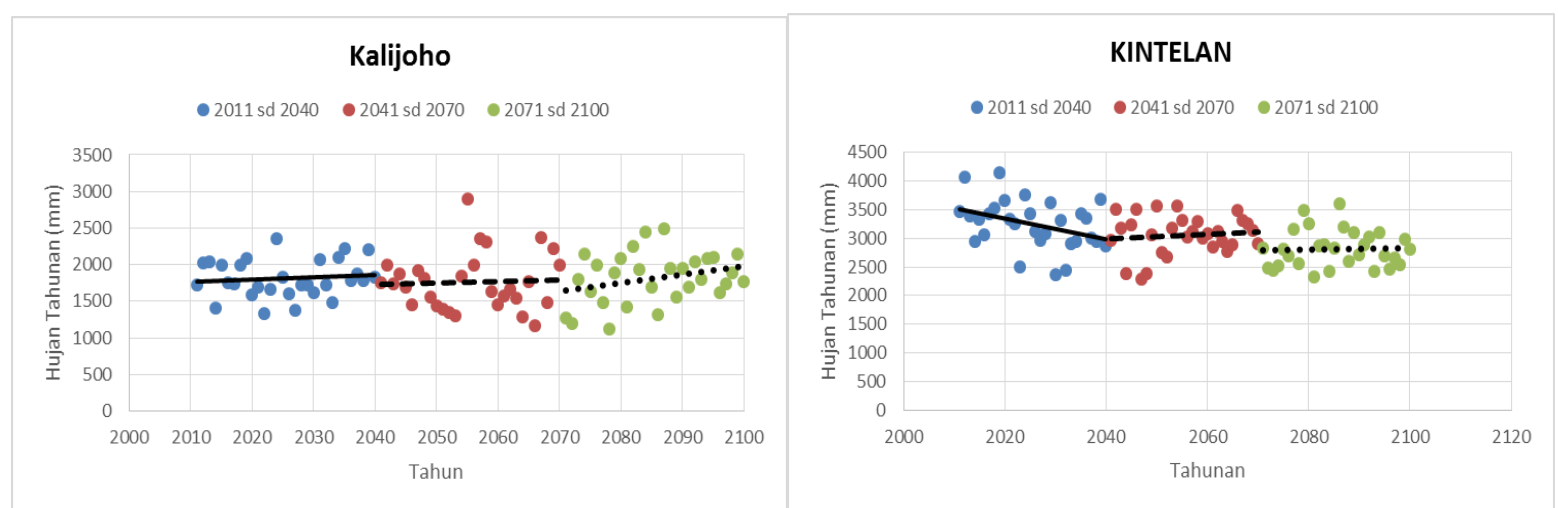

Gambar 10. Perubahan trend curah hujan tahunan pada masing-masing periode iklim di Stasiun Kalijoho dan Kintelan dengan emisi skenario A2 

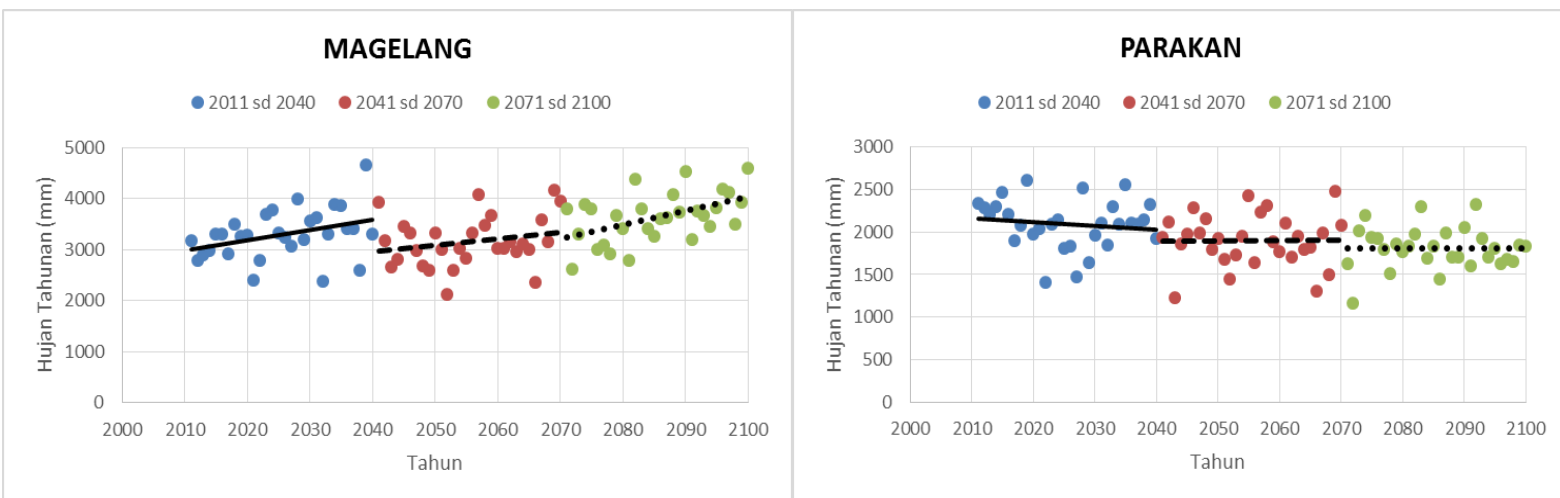

Gambar 11. Perubahan trend curah hujan tahunan pada masing-masing periode iklim di Stasiun Magelang dan Parakan dengan emisi skenario A2

\section{Dampak Perubahan Iklim Terhadap Curah Hujan Tahunan di DAS Progo Hulu dengan Skenario Emisi B2}

Berdasarkan hasil prediksi model perubahan iklim dengan skenario emisi B2 terdapat delapan stasiun pengamatan yang mengalami kenaikan trend curah hujan pada grafik pada Gambar 12. samapai dengan Gambar 16., yaitu: stasiun Babadan, Borobudur, Cebongan, Dukun, Jumprit, Kaliangkrik, Kalijoho, dan Magelang. Sedangkan stasiun yang diprediksi mengalami penurunan trend curah hujan adalah stasiun Kintelan dan Parakan. Namun ditiap periode terdapat kecenderungan nilai curah hujan tersendiri. Lebih jelasnya, trend ditiap periode ditunjukkan pada Gambar 17. sampai dengan 21.

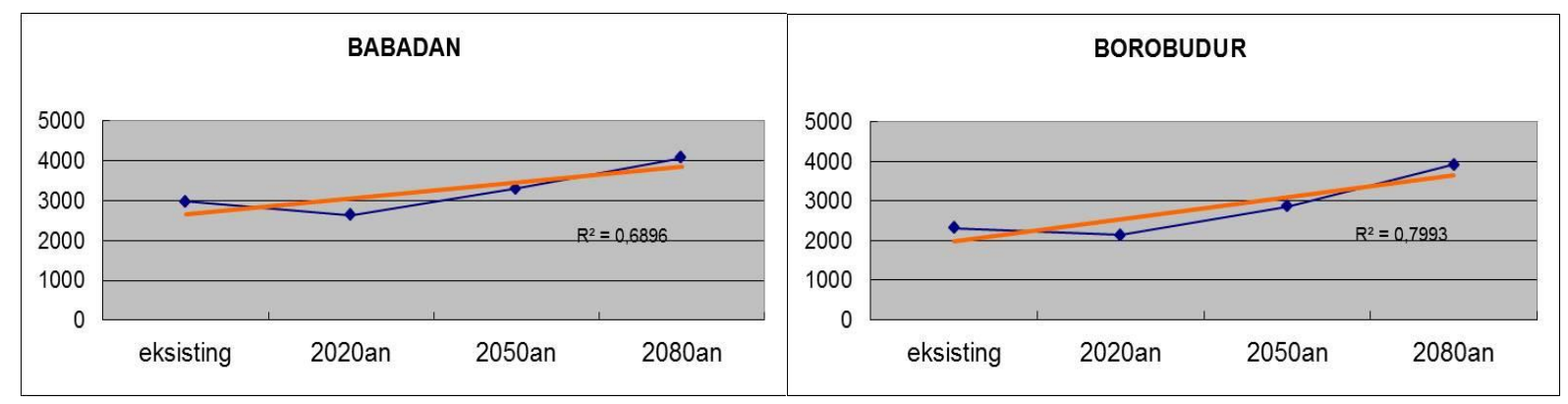

Gambar 12. Perubahan trend curah hujan tahunan di Stasiun Babadan dan Borobudur dengan skenario emisi B2

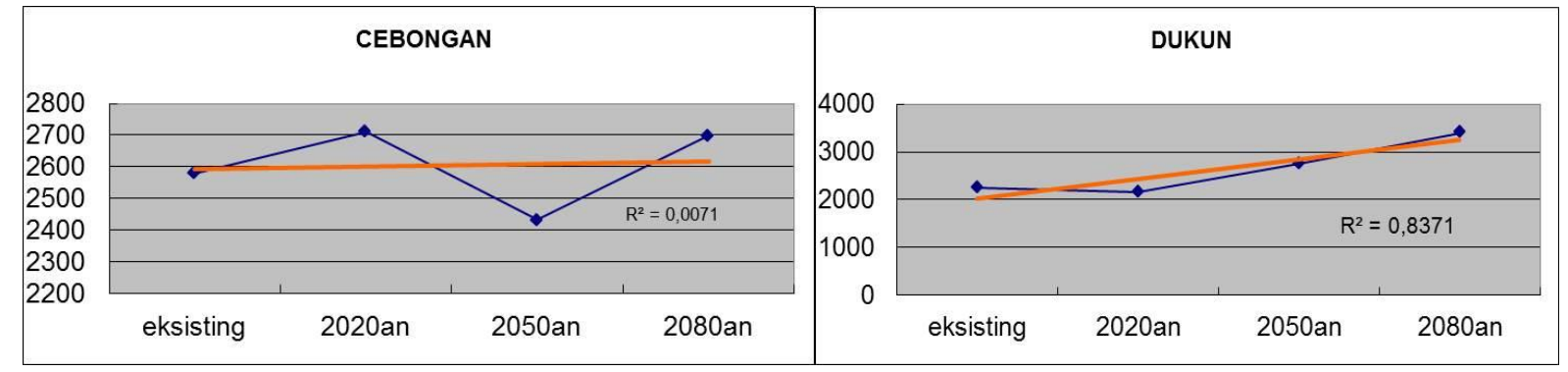

Gambar 13. Perubahan trend curah hujan tahunan di Stasiun Cebongan dan Dukun 


\section{dengan emisi skenario B2}

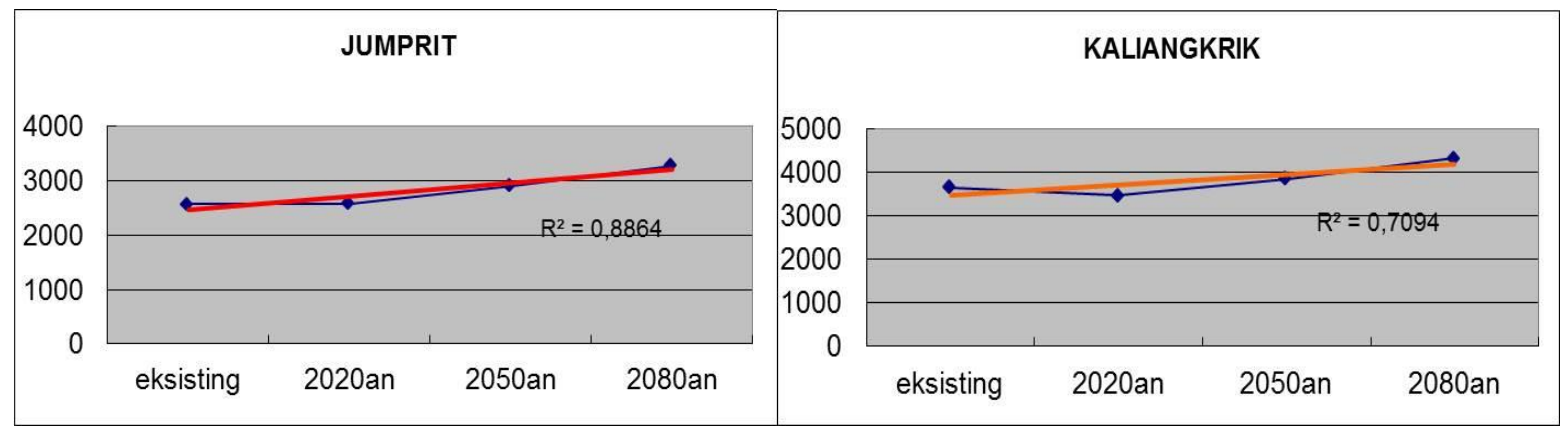

Gambar 14. Perubahan trend curah hujan tahunan di Stasiun Jumprit dan Kaliangkrik dengan skenario emisi B2

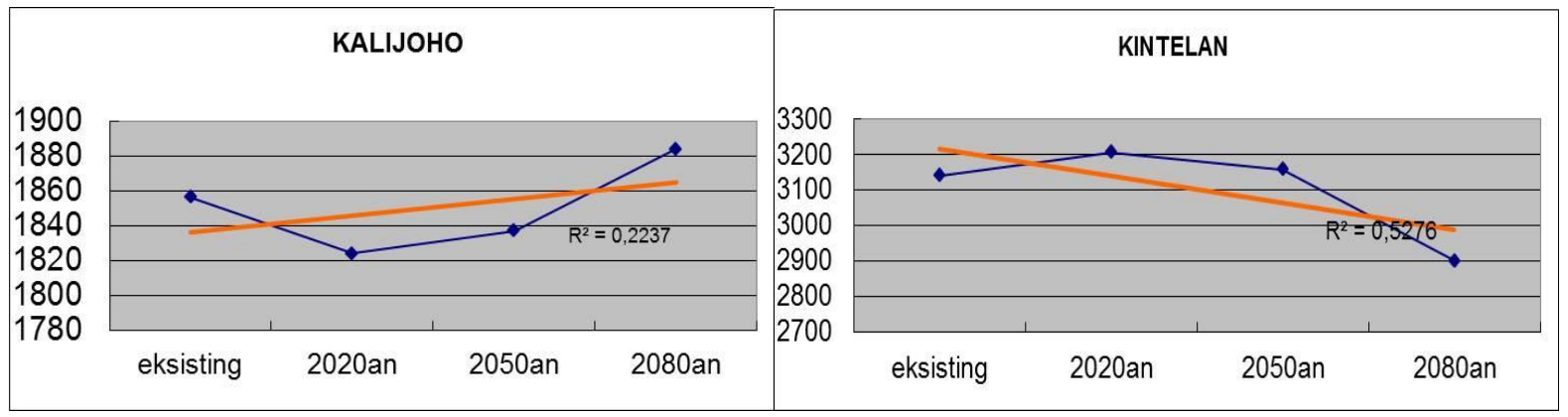

Gambar 15. Perubahan trend curah hujan tahunan di Stasiun Kalijoho dan Kintelan dengan skenario emisi B2

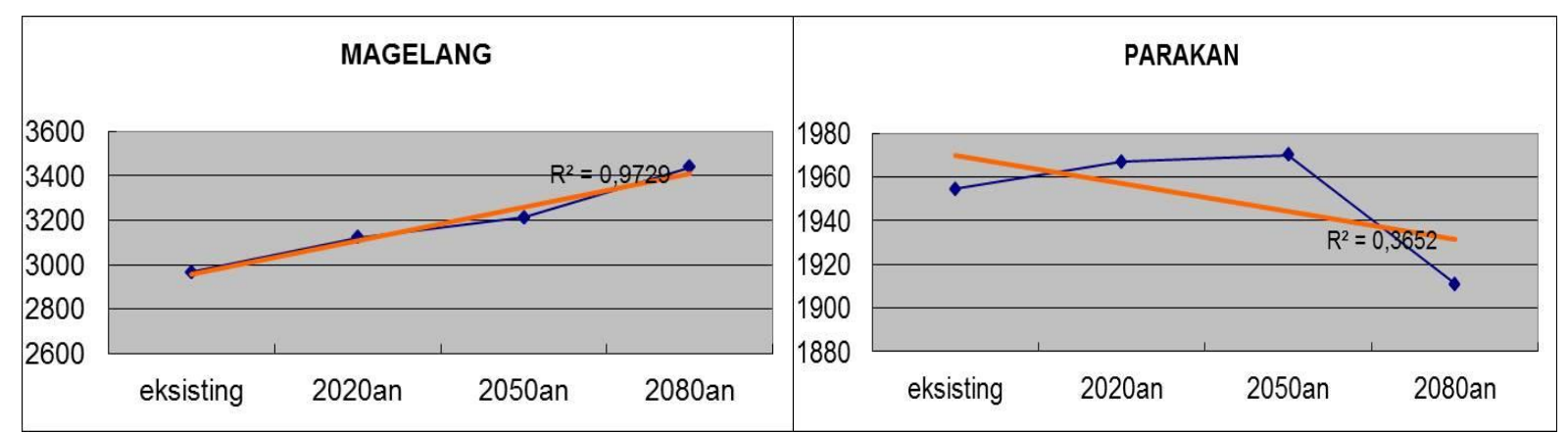

Gambar 16. Perubahan trend curah hujan tahunan di Stasiun Jumprit dan Kaliangkrik dengan skenario emisi B2
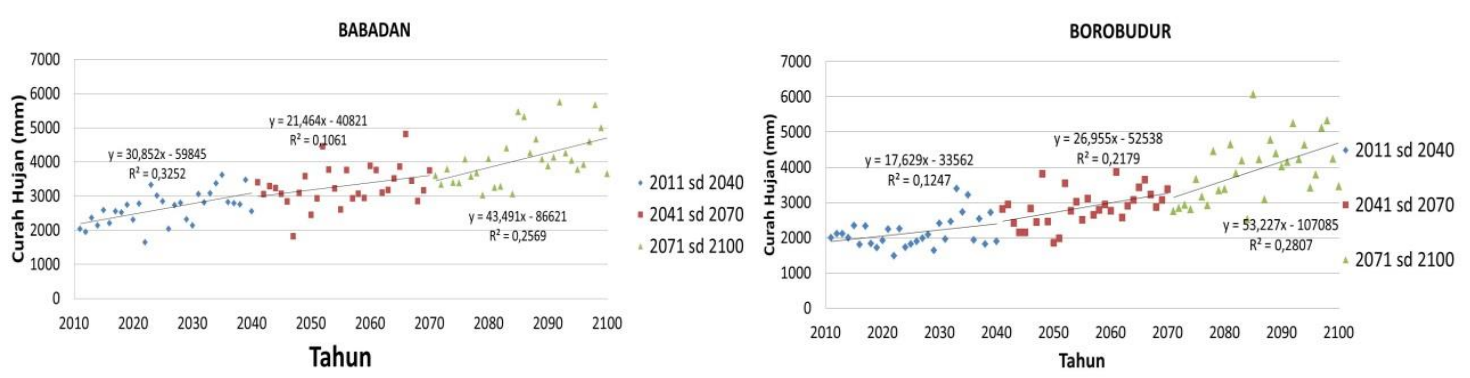
Gambar 17. Perubahan trend curah hujan tahunan pada masing-masing periode iklim di Stasiun Babadan dan Borobudur dengan skenario emisi B2
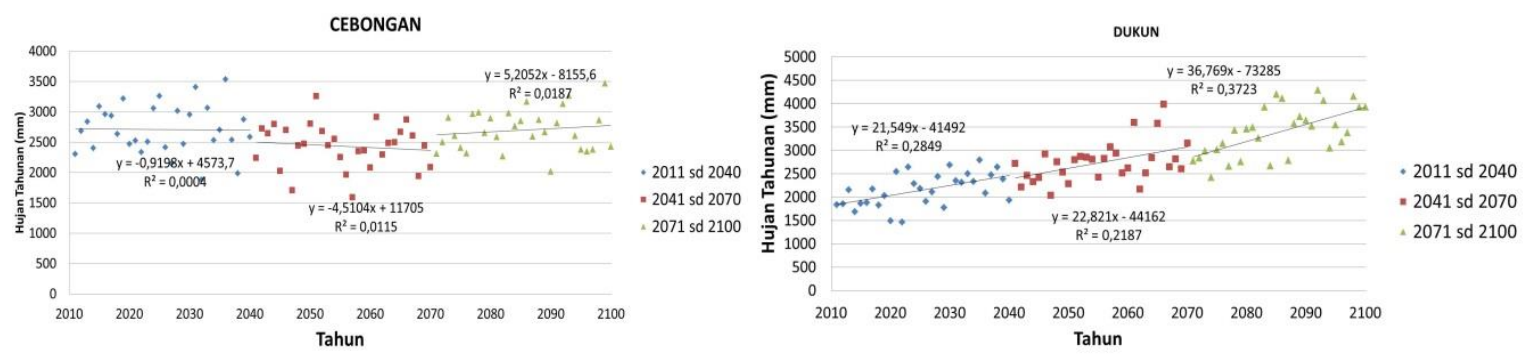

Gambar 18. Perubahan trend curah hujan tahunan pada masing-masing periode iklim di Stasiun Cebongan dan Dukun dengan skenario emisi B2
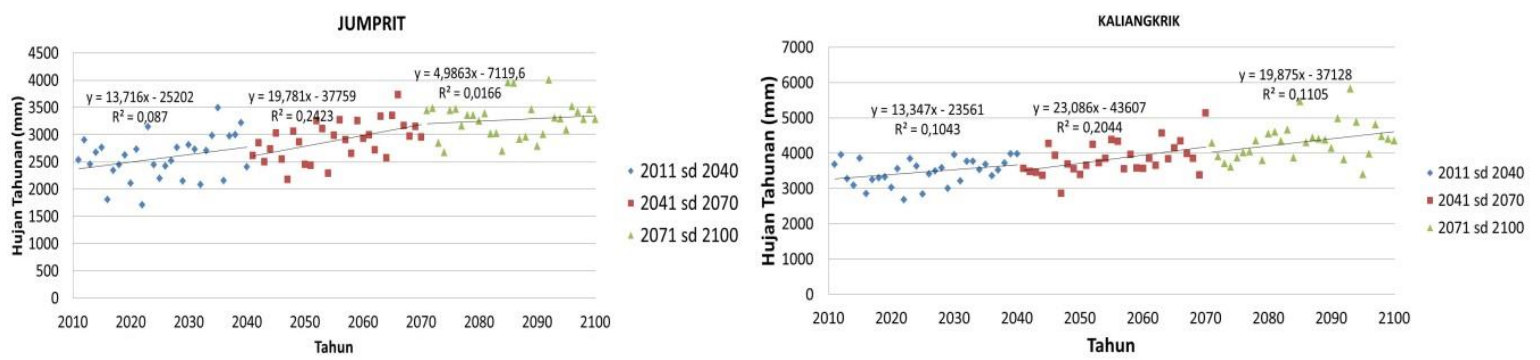

Gambar 19. Perubahan trend curah hujan tahunan pada masing-masing periode iklim di Stasiun Jumprit dan Kaliangkrik dengan skenario emisi B2
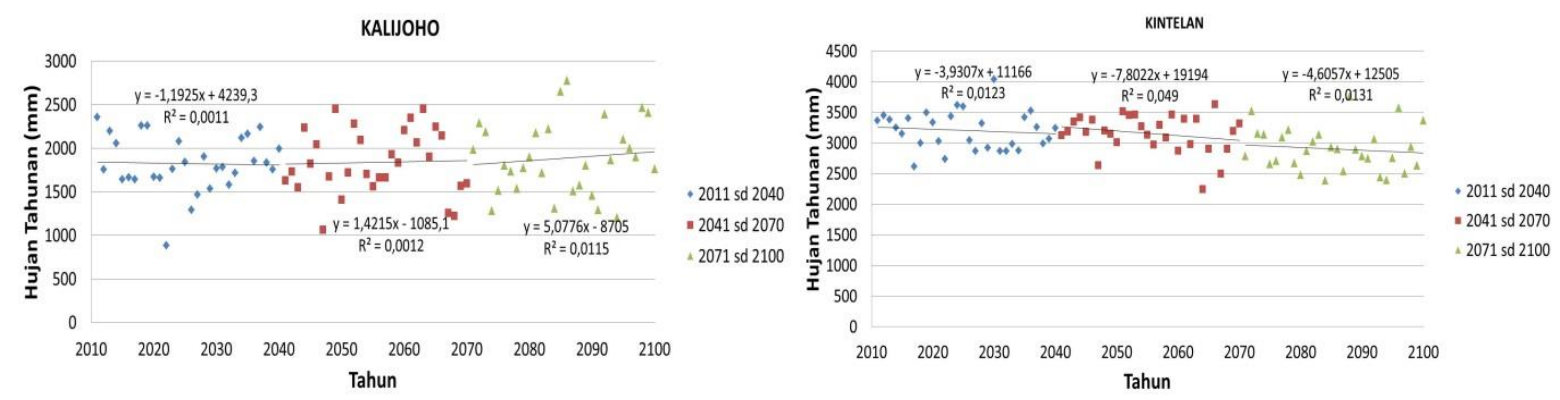

Gambar 20. Perubahan trend curah hujan tahunan pada masing-masing periode iklim di Stasiun Kalijoho dan Kentilan dengan skenario emisi B2
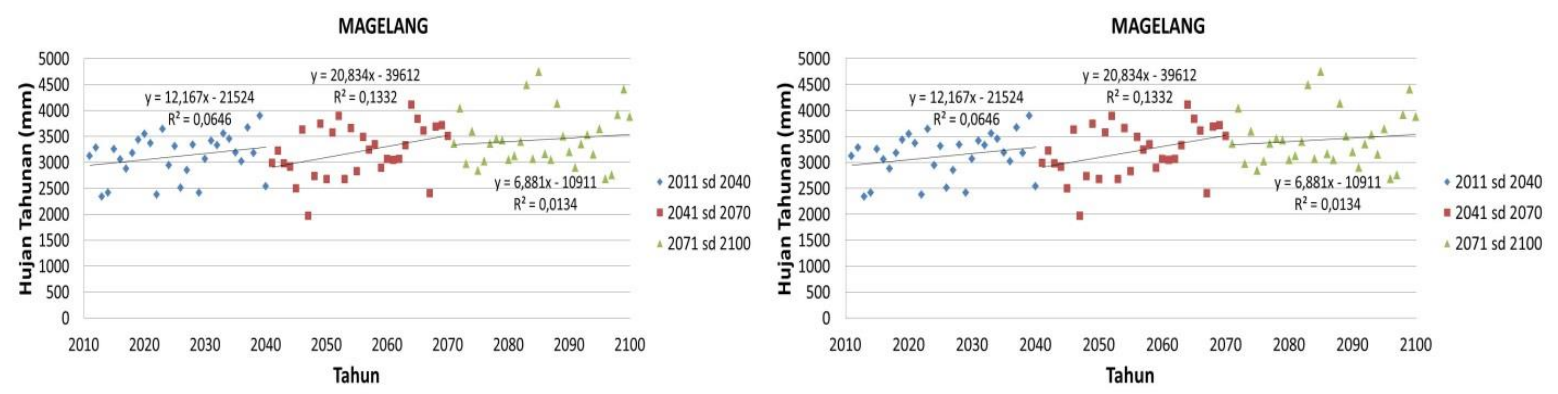

Gambar 21. Perubahan trend curah hujan tahunan pada masing-masing periode iklim di Stasiun Kalijoho dan Kentilan dengan emisi skenario B2 


\section{Kesimpulan}

Hasil kajian penelitian ini berupa dampak perubahan iklim terhadap curah hujan tahunan di DAS Opak Hulu mulai Tahun 2011 sampai dengan 2100 dengan skenario emisi A2 dan B2. Hasil pemodelan perubahan iklim dengan menggunakan skenario emisi A2 menunjukkan 4 stasiun meteorologi menunjukkan jumlah curah hujan tahunan mengalami trend menurun, sedangkan 6 stasiun yang lain mengalami kenaikan. Hasil pemodelan dengan skenario emisi B2 menunjukkan hanya 2 stasiun yang mengalami penurunan curah hujan, sedangkan 8 stasiun yang lain di DAS Progo Hulu mengalami trend kenaikan curah hujan tahunan.

\section{Pengakuan}

Penelitian ini merupakan bagian dari penelitian Hibah Bersaing Pascasarja Universitas Gadjah Mada 2014 dengan judul "Estimasi Dampak Perubahan Iklim Terhadap Produktivitas Pertanian Sampai Tahun 2100 Berdasarkan Skenario Perubahan Iklim HadCM3 dan Skenario Emisi A2 dan B2 di DAS Progo Hulu”.

\section{Daftar Pustaka}

Viglizzo, E.F., Roberto, Z.E., Filippin, M.C., Pordomingo, A.J. 1995. Climate Variability and Agroecological Change in The Central Pampas of Argentina. Agriculture, Ecosystems \& Environment, Vol. 55. Hal: 7-16.

Plummer N, Salinger MJ, Nicholls N, dkk. (1999) Changes in Climate Extremes over The Australian Region and New Zealand During The Twentieth Century. Climatic Change, Vol. 42. Hal: 183-202.

Mason, S.J. 1996. Climatic Change Over the Lowveld of South Africa. Climatic Change, Vol. 32. Hal: 35-54.

Masoudi, M., Afrough, E. 2011. Analyzing Trends of Precipitation for Humid, Normal and Drought Classes using Standardized Precipitation Index (SPI), A Case of Study: Fars Province, Iran. International Journal of AgriScience Vol. 1(2). Hal: 58-69.

Wilby, R.L., dan Dawson, C.W. 2008. Using SDSM - A Decision Support Tool for The Assessment of Regional Climate Change Impacts. United Kingdom: National Centre for Risk Analysis and Option Appraisal, UK Environment Agency

Zhai, P.M., Sun, A.J., Ren, F.M., Liu, X.L., Gao, B., Zhang, Q. 1999. Changes of Climate Extremes in China. Climatic Change, Vol. 42. Hal: 203-218. 